\title{
Developing Instructional Media Mobile Learning Based Android to Improve Learning Outcomes
}

\author{
Candra Irawan', Ery Tri Djatmika RWW2 \\ Department of Management, Universitas Negeri Malang \\ E-mail: candrairawan0711@gmail.com
}

\begin{abstract}
This research aims to develop instructional media which is tested its feasibility and piloted in learning activities. The instructional media is developed using online builder Appypie with DCE developedmodel. The product assessment is conducted by material expert, media expert and testing in a small and big group.The instrument of collected data is conducted by interviewing, questionnaire and test. The results of this research are: The instructional media product, mobile learning based android, has been using online builde Appypie, instructional media is feasible to apply after obtaining assessment result from material and media expert and users, The learning outcomes increases significantly between students with and without using instructional media. In summary, developed instructional media is feasible to app;y in a learning activity.
\end{abstract}

Keywords: Instructional Media, Mobile Learning, Learning Outcomes

\section{INTRODUCTION}

The learning purpose will be successful if it is supported by several elements. One of the elements influencing learning purposes is the use of instructional media (Naz and Akbar, 2008). The instructional media intends to assist teachers presenting the materials to their students (Gan et al., 2015). Teachers can implement it to avoid boredom during the class and to increase learning outcomes. (Vebrianto and Osman, 2011). The use of instructional media should be adjusted with the needs and presented materials (Sangsawang, 2015). The development of Science and Technology brings impact toward several aspects of life including education (Büyükbaykal, 2015). The existence of gadget, such as smartphone and tablet, is useful to support daily activity in society (Tan et al., 2018). Almost everyone now use the cheap and easy to use smartphone including students (Nayak, 2018). Smartphone is not only as communication tools, but also a fantastic instructional media to use (Chen, 2018). The use of instructional media in learning activities is one of the ways to lose boredom and monotonous. Instructional media mobile learning is a medium to use gadget so that learning is able to do everywhere and every time (Ozdamlia and Cavus, 2011).

The mobile learning creation is to response the rapid development of Science and Technology particularly the use of smartphone (Crompton and Burke, 2018). Students can review materials deeply without searching to find other sources to other places. According to the educators perspective, mobile learning is an effective media as it is available on their tools (Hunaiyyan et al., 2018). This instructional media brings many advantages in education and must be used well 
(Hamidi and Chavoshi, 2018). The existing mobile learning, in fact, cannot replace the face-to-face classroom learning. Mobile learning tends to be complement of learning to hopefully increase learning outcomes and students motivation (Emran et al., 2016).

The result of the interview conducted with one of Vocational High School in East Java Indonesia that teachers experience some problems during the learning activities peculiarly in learning sources. This subject are new in 2013 Curriculum 2017 Revision, so that the stock of book, worksheets (LKS), and other sources is limited. Other problem that teachers find is the minim time in learning. The immense of subjects is imbalance with the amount of hours so that teachers is hard to manage learning schedule, Besides that, teachers present the materials only using power point with once in a while replacing the methods. From the several problems faced in school, it is plausible to find the solution. In this subject, the students are free to operate the smart-phone as a complement material. For the limited teachers, they let their students to find additional materials from internet to complete the missing material that make the students' understanding is more complex. In this study, the researchers use instructional media based-android mobile learning in order to increase the students performance in class. Through this medium, the students are expected to be more motivated to follow the learning activities in Public Administration. Besides that, students are more flexible to study everywhere and anywhere without spaces and condition borders.

\section{METHOD}

This research is a Research \& Development research using DCE (Design, Construction, and Evaluation) development. The type of data is qualitative and quantitative. The qualitative data are collected from critics and suggestion from media expert, material expert and field study (users). In the other hand, the quantitative data are collected from questionnaire from media expert, material expert, respondents (students) and post test score to identify the difference of result study between with and without instructional media. The subject of experiment in this research is thirty six students in experiment and control classrooms for each. The learning activities in both classes are same using student centered. However, the control class does not apply instructional media mobile learning android based developed by the researcher. The learning source applied in control class students comes from school library books. The research instrument used are interview, questionnaire, and test. The interview is conducted to teachers to identify the current problems and potency in school and to investigate more information of the running classroom. The questionnaire aims to aware of media feasibility upon developed instructional media. Moreover, test is conducted through post-test aiming to compare the student improvement in learning activity between experiment and control class. 


\section{RESULTS \& DISCUSSION \\ Result}

Instructional media mobile learning based android in office tools has been created using online builder Appypie based on DCE steps. The media creation intends to increase the students' outcomes These are steps conducted by researcher to create instructional media using DCE method. The first step is Design. After obtaining learning tools such as syllabus from Public Administration teachers, the next step is to analyse syllabus. From the syllabus, it is clear to know what should be prepared including the materials and exercises in the form of 15 multiple choices and 10 essays to use in instructional media.It is important to give exercises as a student skill evaluation mastering material. The evaluation should be balance and meaningful based on contained learning material (Parsazadeh et al., 2018). In this step, there is storyboard to divide prepared material into sub-material to be an icon in instructional media. The instructional media menu can be looked at this figure.

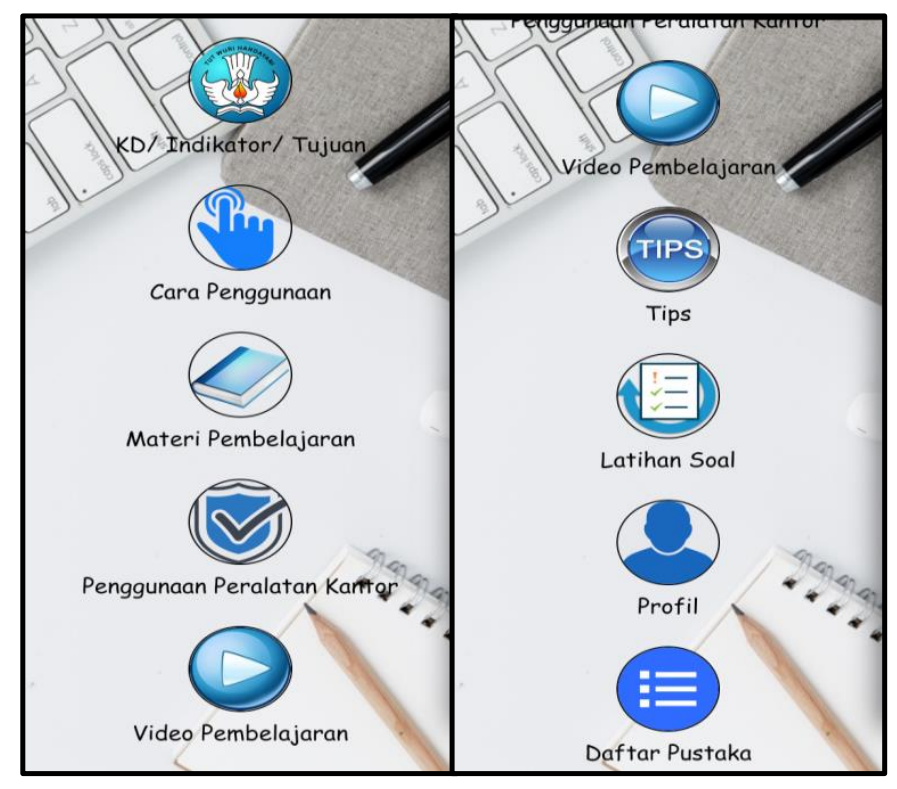

Figure 1. Instructional Media Menu

The second step is Construction. After design step is done, the next step is to make instructional media mobile learning based android in accordance to storyboard abd prepared material. The creation of this instructional media implemented online builder Appypie is available to access online through www.appypie.com. The next step is Evaluation. In this step, the instructional media is installed on smartphone and validated to give evidence that the created media is feasible to use for learning. The result of validation from material expert, media expert, and users as follow Figure 2. 


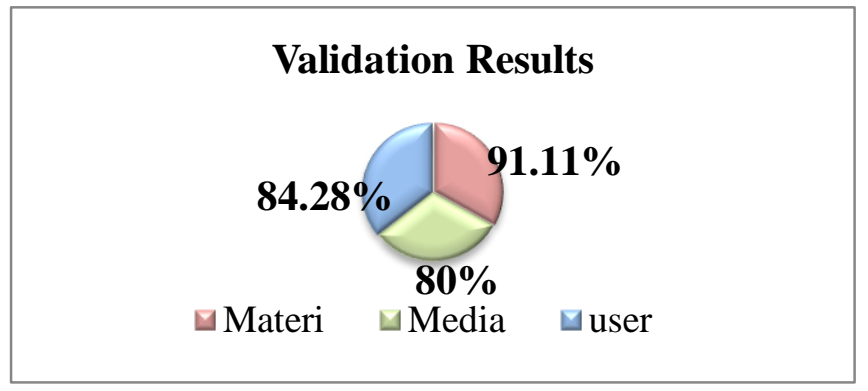

Figure 2. The Result of The Feasibility of instructional media

The Figure 2 shows that the developed instructional media mobile learning based android has been feasible to apply in the learning activities. Material and media experts convey that this instructional media attract students in the easiness to operate. From students' perspective, the instructional media mobile learning increase the effectiveness and efficient of learning, to boost the students' spirit and to help understanding learning materials (Jeno et al., 2017). These are the pictures of instructional media:

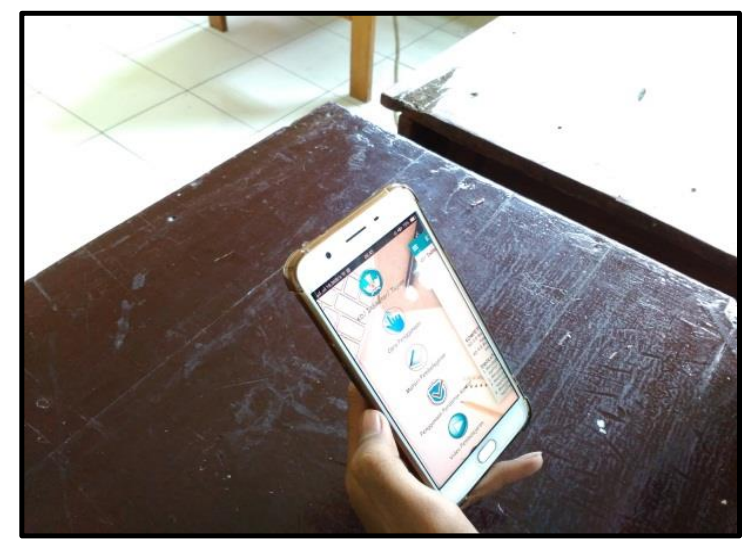

Figure 3. The use of instructional media

The advantages of the use instructional media mobil instructional media(1) To help teachers and students learning materials as the media is possible to use everywhere and anytime that should not require them to go to some places finding learning sources (Ozdamlia and Cavus, 2011). (2) instructional media is completed with the guidance of tutorial video so that the users are able to easily use it (Nasir and Bargstädt, 2017). (3) The materials are presented coherently and systematically so that allowing users to learn the office tools materials. Students are able to study independently so therefore can help teacher handle the limited learning schedule (Miloševic et al., 2015). (5) The instructional media is completed with the learning pictures and videos to support students' understanding (Biard et al., 2017). (6) Containing exercises in the form of interactive multiple choices that students are able to finish and to know the result so that they recognize their ability and understanding. This instructional media in this research has brought many advantages in learning activities. Besides the aforementioned use, this instructional media also have some weaknesses to implement as follows: (1) The 
instructional media is online so that if there is no internet connection, the smartphone cannot be operated. (2) The instructional media is unpaid media so that there are some advertisement during the operation.

The learning outcomes is the most important part from the education and very correlated to the goal of learning achievement. In this research and development, the researcher use two classes namely experiment and control classroom. The choice of both classes is based on the suggestion from the Public Administration and the result of the pre-test showing that there is gap between those two classes. The learning activities conducted in the experiment class is added with the instructional media mobile learning based android. Every student has android smartphone connected with school Wi-Fi to access this instructional media. The students can use the instructional media independently and complement their learning.

Most of the learning activities in control class is almost same with experiment class that is student-centered. However, during the control class does not use the mobile learning based android developed by the researcher. The source of learning used by students is borrowed-book from school library. The result of the pre test and post test can be seen at this Table 1 as follows.

Table 1. The Students learning outcomes

\begin{tabular}{lcc}
\multicolumn{1}{c}{ Class } & \multicolumn{2}{c}{ Score } \\
\cline { 2 - 3 } & Pre Test & Post Test \\
\hline Control Class & 78.06 & 80 \\
Experiment Class & 80 & 94.71 \\
\hline
\end{tabular}

The result of the pre-test shows that there is significance difference from both classes. The experiment class has higher score comparing to control class. The different between those two classes is from several factors. Those factors are the less of learning source and learning schedule in the control class.

\section{Discussion}

The learning source used by the control class is from library books only. Comparing to experiment class, the students do not only borrow books from library but also they use instructional media mobile learning based android. The mobile learning is completed with materials in the form of text, pictures, videos learning and exercise that increase their understanding upon the materials. The smartphone used for instructional media enrich the learning methods and to ease the users accessing learning materials (Teodorescu, 2015).

The use of the mobile learning in the form of handphone shows that this leaning media is flexible which is veru easy to bring everywhere (Ozdamlia and Cavus, 2011). Thus, the students in the experiment can use their learning hours everywhere and every time as they only have twice of face-to-face classes in the basic skill of Choosing Office Utilize in this Administration Activities. From the educators perspective, mobile learning brings positive impact upon the learning where technology increases motivation and participation of students (Taleb et al., 2015). According to that comparison, to conclude that the learning activities using 
instructional media mobile learning based android can increase the result learning of students.

\section{CONCLUSION}

According to the conducted research and development, there are several conclusion as follows, (1) The result of research and development in the form of instructional media mobile learning android based in the Public Administration. The instructional media is created using online builder Appypie containing elements of text, pictures, video and exercises to support the understanding of students during the study. 2) The developed instructional media has passed the validation process, including material and media validation. From this testing, the average score was about 85.13 percent that shows the feasibility of the instructional media. (3) The use of instructional media mobile learning based android can increase the result study of the students. The students who uses instructional media has about 94.71 score. Whereas, the students with no instructional media has about 80. From the result, it is known that the difference of result study reach 14.7 point. Therefore, the use of instructional media mobile learning based android boost the result study of the students.

\section{REFERENCES}

Biard, N., Cojean, S., and Jamet, E. 2017. Effects of segmentation and pacing on procedural learning by video. Computers in Human Behavior. 49, 411-417. https://doi.org/10.1016/j.chb.2017.12.002

Büyükbaykal, C.I. 2015. Communication technologies and education in the information Age. Procedia Social and Behavioral Sciences.174, 636 - 640. https://doi.org/10.1016/j.sbspro.2015.01.594

Chen, C.P. 2018. Understanding mobile English-learning gaming adopters in the self-learning market: The Uses and Gratification Expectancy Model. $\begin{array}{llll}\text { Computers } \& \text { Education. } & \text { 217-230. }\end{array}$ https://doi.org/10.1016/j.compedu.2018.07.015

Emran, M.A., Elsherif, H.M., Shaalan, K. 2016. Investigating attitudes towards the use of mobile learning in higher education. Computers in Human Behavior. 56, 93-102. https://doi.org/10.1016/j.chb.2015.11.033

Gan, B., Menkhoff, T., and Smith, R. 2015. Enhancing students' learning process through interactive digital media: New opportunities for collaborative learning. Computers in Human Behavior. 51, 652-663. https://doi.org/10.1016/j.chb.2014.12.048

Hamidi, H., and Chavoshi, A. 2018. Analysis of the Essential Factors for the Adoption of Mobile Learning in Higher Education: A Case Study of Students of the University of Technology. Telematics and Informatics. 35, 10531070. https://doi.org/10.1016/j.tele.2017.09.016

Hunaiyyan, A.A., Alhajri, R.A., Sharhan, S.A. 2018. Perceptions and challenges of mobile learning in Kuwait. Journal of King Saud University - Computer and Information Sciences 30(2), 279-289. https://doi.org/10.1016/j.jksuci.2016.12.001 
Jeno, L.M., Grytnes, J.A., and Vandvik, V. 2017. The effect of a mobile-application tool on biology students' motivation and achievement in species identification: A Self-Determination Theory perspective. Computers \& Education. 107, 1-12. https://doi.org/10.1016/j.compedu.2016.12.011

Miloševic, I., Živkovic', D.,Manasijevic', D., and Nikolic', D. 2015. The effects of the intended behavior of students in the use of M-learning. Computers in Human Behavior. 51, 207-215. https://doi.org/10.1016/j.chb.2015.04.041

Nasir, A.R., and Bargstädt, H.J. 2017. An approach to develop video tutorials for construction tasks. Prodecia Engineering. 196, 1088-1097. https://doi.org/10.1016/j.proeng.2017.08.066

Nayak, J.K. 2018. Relationship among smartphone usage, addiction, academic performance and the moderating role of gender: A study of higher education students in India. Computers \& Education. 123, 164-173. https://doi.org/10.1016/j.compedu.2018.05.007

Naz, A.A., and Akbar, R.A. 2008. Use of Media for Efeective Instruction its Importance: Some Consideration. Journal of Elementary Education A Publication of Deptt. of Elementary Education. 18, 35-40.

Ozdamlia, F., and Cavus, N. 2011. Basic elements and characteristics of mobile learning. Procedia Social and Behavioral Sciences. 28, 937 - 942. https://doi.org/10.1016/j.sbspro.2011.11.173

Parsazadeh, N., Ali, R., and Rezaei, M. 2018. A framework for cooperative and interactive mobile learning to improve online information evaluation skills. $\begin{array}{lllll}\text { Computers } \& \quad \text { Education. } & \text { 75-89. }\end{array}$ https://doi.org/10.1016/j.compedu.2018.01.010

Sangsawang, T. 2015. Instructional design framework for educational media. Procedia Social and Behavioral Sciences. 176, 65 - 80. https://doi.org/10.1016/j.sbspro.2015.01.445

Taleb, Z., Ahmadi, A., and Musavi, M. 2015. The Effect of M-learning on Mathematics Learning. Procedia Social and Behavioral Sciences. 171, 83-89. https://doi.org/10.1016/j.sbspro.2015.01.092

Tan, W.K., Hsiao, Y.J., Tseng, S.F., and Chan, C.L. 2018. Smartphone Application Personality and Its Relationship to Personalities of Smartphone Users and Social Capital Accrued through Use of Smartphone Social Applications. Telematics and Informatics. 35 (1), 255-266. https://doi.org/10.1016/j.tele.2017.11.007

Teodorescu, A. 2015. Mobile learning and its impact on business English learning. Procedia - Social and Behavioral Sciences. 180, 1535 - 1540. https://doi.org/10.1016/j.sbspro.2015.02.303

Vebrianto, R. and Osman, K. 2011. The effect of multiple media instruction in improving students' science process skill and achievement. Procedia Social and Behavioral Sciences. 15, 346-350. https://doi.org/10.1016/j.sbspro.2011.03.099 